\title{
The Effectiveness of Entrepreneurial Activities for Economic Development: A Route to Innovation and Job Generation
}

\author{
Md Yusuf Hossein Khan
}

PhD Researcher in Tourism, University of Algarve, Portugal;

Assistant Professor, College of Tourism and Hospitality Management, IUBAT - International University of Business Agriculture and Technology, Bangladesh

\begin{abstract}
Entrepreneurship is one of the most important input in the economic development of a country by which it creates new jobs and brings innovation. Economic development of a country is the outcome of determined social activity and in particular human. Thus, it is a fact that entrepreneurship plays a significant role in shaping the economy of a country. Nowadays, one of the key objectives of modern economics is to determine factors that influence the economic development and entrepreneurship could easily be considered as one of the factors that influence the economy, either directly or indirectly. Despite the global downturn entrepreneurs are enjoying because governments provide facilities to entrepreneurs in various ways because any country can be productive within the boundary of entrepreneurial activities. More and more entrepreneurial activity is shifted toward productive entrepreneurship since the government of money countries. Governments are trying to support the economic development of a country for economic development.

In this report, the main objective was to identify the critical literature about international entrepreneurship and economic development in order to assess the effectiveness of entrepreneurial activities for economic development. Using different kinds of literatures from research papers, articles, books this paper highlights and examines the importance of entrepreneur activities and how these actions contribute towards innovation and job generation. Through the literature, the author has also tried to bring the facts into attention why many countries in the past and the recent global economic world providing many facilities to the entrepreneurs and as a followthrough what outcomes are being recorded. The following paper aims to create awareness among the academicians, government officials, politicians the effectiveness of entrepreneurial activities for economic development. To know the impact of international entrepreneurship for economic development critical literature about the topic has given below.
\end{abstract}

Keywords: entrepreneur, economic development, government, facility, innovation.

JEL Classification: L26.

(C) The Author, 2018. This article is published with open access at Sumy State University.

\section{Introduction}

\section{Background of the study}

Entrepreneurship activities or the increase in business ownership plays an important role in economic development. For this reason, it is considered an important mechanism for national economic development (Acs, 2006). Various authors worked on the topic of international entrepreneurship and economic development. Manu of them cited different views from their research and findings. Despite the global downturn entrepreneurs are enjoying because governments provide facilities to entrepreneurs in various ways because any country can be productive within the boundary of entrepreneurial activities. More and more entrepreneurial activity is shifted toward productive entrepreneurship since the government of money countries. Governments are trying to support the economic development of a country for economic development. Audretsch (2001) made an important observation that entrepreneurial activity is typically associated with higher income and growth through innovation. Therefore, entrepreneurship is inherently responsible for economic development of a country. Governments are trying to identify their productive and unproductive areas to promote entrepreneurial activities in the productive sector for further improvement in productive sectors and introduce innovative means of business for the growth of the business (Berkowitz and Holland, 2011).

In this paper, the main objective was to identify the critical literature about international entrepreneurship and economic development in order to assess the effectiveness of entrepreneurial activities for economic 
development. To know the impact of international entrepreneurship for economic development critical literature about the topic has given below.

\section{Literature review}

\section{Theories of entrepreneurship}

Various theories have been proposed about entrepreneurship. For example, economic theories, resources based theories, psychological theories, sociological theories and opportunity based theories of entrepreneurship. This report is basically an overview of the critical literature review of economic theory, resources based theory and opportunity based theory.

The Economic theory of entrepreneurship focused on the economic conditions and entrepreneurial opportunity creation. Resources based theories are also related to the economic development of a country since an economy is the provider of resources to the entrepreneurs. Access to the resources to create new ventures is necessary to start and operate a new venture. Finally, the opportunity based theory suggests that cultural, social and technological changes create opportunities for entrepreneurs to start a new venture. It creates a room for invention for the entrepreneurs (Buckley, 1989).

To define key concepts of international entrepreneurship and economic development, this paper has outlined the key concepts of international entrepreneurship and economic development through critical literature.

\section{Key concepts of international entrepreneurship and economic development}

Cavusgil and Knight (2015) defined international entrepreneurship as discovery, enactment, evaluation, and exploration of opportunities across national borders to create future goods and services. Covin and Slevin (1989) said the entrepreneurship is the creation of new economic activity. Davidsson (1995) supported this view but he added that the entrepreneurial features are also associated with innovation, risk-taking, and proactiveness. International entrepreneurship is a broader view of local entrepreneurship. When entrepreneurial activities go across the border, it creates opportunities for businesses to include new venture internationalization and SME internationalization. Etzioni (1987) said that when we study the cross-border or international entrepreneurship concept then we need to study the entrepreneurship activities and facilities for multiple countries. The field of international entrepreneurship and has been studied from various perspectives but when researchers dealt with the economic context they focused on the economic importance and value of entrepreneurship. Economic development can be approached through different ways such as structural change, government support, accumulation of human capital, urbanization, growing level of education, income distribution etc. Again, growing level of per capita income, trends for innovation, worldwide diffusion of new information, improved communication technology are the major drivers of entrepreneurship rate (Fletcher, 2011).

\section{Theories for the support of internal entrepreneurship and economic development}

Ilmakunnas and Kanniainen (2001) found a U-shaped relationship between economic development and entrepreneurship. Johnson (2004) analysed the economic theory of entrepreneurship and acknowledged that social and cultural change support the entrepreneurial activity. He found that in a highly developed economy entrepreneurial risk can be minimised through job creation from the self-employed person and one for the person who works in the entrepreneurial sector. Again Koellinger (2008) observed that a decline in the economic condition of a leads to decline in good jobs and tends to increase the level of self-employment. According to Lumpkin and Dess (1996), entrepreneurship is at the heart of national advantage. He said that there is eminent importance of entrepreneurship for the economy because entrepreneurs carry out the feature like innovation. There is ample evidence that many large firms moved away from large activity to small business activity in the 1970s and in 1980s. McDougall (1989) pointed out that necessary shift towards a knowledge-based economy is a consequence of entrepreneurial business activities and increasing small business firms in an economy. Small business firms are created because of the increase in start-up businesses. But the reasons behind starting up new small businesses are that entrepreneurs are the routes of innovation and job generation, for this reason, SMEs tend to stimulate the economic growth of the country. Noorderhaven et al. (2004) stressed on the role innovative activities. He said that small entrepreneurial ventures are an agent of change of the economic condition of a country by their entrepreneurial activities.

Oviatt and McDougall (2005) emphasized on the role of entrepreneurs in functioning the market. He found a positive relationship between the impact of entrepreneurship and the GDP growth and employment. Scherer (2002) articulated that higher levels of entrepreneurship reduce the level of unemployment. The mechanism of 
technological progress and economic development is widely recognized and innovative entrepreneurs play a key role in this case. Innovative entrepreneurs introduce new invention and technological process to business firms and thus they influence productivity. Thurik et al. (2008)found that during the last 25 years of the 20th century a third industrial revolution has occurred with the emergence of new industries like software and biotechnological industries and small firms are playing an important role for the improvement of these industries because small firms have a relative innovative advantage over the large firms. Moreover, much small technology-based are now challenging the large companies because of this advantage. Yamada (1996) argued that it is far less valuable for people to be in the same geographical location to work together effectively. This concept was also supported by by Zahra (2004). Understand the impact of entrepreneurial activities on the economic development government acknowledged the role of small firms in the economy and are trying to promote entrepreneurial activities.

\section{Theories of the international entrepreneurship and economic development}

Acs (2006) argued that the U-shaped relationship might not be valid as a measure of business ownership rate. This is because modern entrepreneurs are now related to high level of globalization, advanced information and communication technology. Audretsch (2001) said that economic growth is mainly restricted to the realm of macroeconomics. The Economic condition of a country is shaped by the degree of industry structure and utilization of acre resources, not entrepreneurial activities. Berkowitz and Holland (2011) said that a change in the economic growth is associated with the change in industry structure. Buckley (1989) provided evidence that not only entrepreneurial manufacturing activity rather both manufacturing and service sector entrepreneurial activity is important for economic development of a country. The role of small business firms for job creation is controversial because firm size is an important factor for job creation. Small firms are not able to create ample job offerings whereas large firms can do that. Moreover, diversity of obtaining technological process is less in the small firms than the large firms. For this reason, small entrepreneurial ventures are not able to support the economic growth of a country.

Cavusgil and Knight (2015) argue that entrepreneurship concept and small business concept are not synonymous. Although small businesses are a vehicle for entrepreneurial ambitions for individuals, the small firms are basically an extension of the individual in charge. Covin and Slevin, (1989) said that although productivity rises because of technological development and inventions, entrepreneurs make the current product and technologies obsolete. This process is known as the process of creative destruction. According to Davidson (1995), large firms are able to invest in R\&D activities more than the smaller firms. So, entrepreneurs are not the prime change agent of an economy through invention and technological improvement. The 20th century is a period of accumulation because at these period hierarchical industries were growing progressively and exploited various scopes of business like production, $R \& D$, distribution and marketing (Georgiou, 2011). As a result, the presence of small firms was declining which means that smaller firm cannot sustain for the long term because of the market power of the large firms. With a decline in the smaller firms, large firms tend to more strength in the market. At this time government was supporting the large businesses also. For this reason, Fletcher (2011) argued that not small entrepreneurial ventures rather larger firms are the main economic change agent. Etzioni (1987) reported a negative relationship between business ownership rate and economic development. Many small start-ups like internet-based small businesses from the late 1990s are struggling to survive in the newly emerged industries (Han and McKelvey, 2008). Ilmakunnas and Kanniainen (2001) said the entrepreneurs are just playing the role of innovator but Koellinger (2008) argued that there are three entrepreneur roles that boost up the growth of economic development.

\section{Theory against and theory for international entrepreneurship and economic development}

Johnson (2004) said that small firms are stimulating the economic growth by increasing the productivity of a country since they are the suppliers of new and specialized products to the large firms. But Lumpkin and Dess (1996) argued that small firms are not able to support the large firms with their products because large firms focused on the core competencies of the business for which they try to invest more on R\&D activities to improve the product and service quality. But small firms are unable to invest that large sum for R\&D and as a result, they cannot provide with standard products to large firms. On the contrary, McDougall (1989) suggested that large firms are not able to enter in such market niches and for this reason; they depend on the small firm's productivity. Noorderhaven et al. (2004) articulated that introduction of new technologies is positively related to the stage of economic development. Oviatt and McDougall (2005) said that entrepreneurs are playing three roles as a change agent of economic development. He said that entrepreneurs are an innovator, profit seeker, 
and risk taker. When searching for the link between entrepreneurship and growth. Scherer (2002) proposed that creating new opportunities for entrepreneurship need more attention. But Zahra (2004) argued that it is necessary to focus on the competitive dimension of entrepreneurship also.

Thurik et al. (2008) said that an entrepreneur is stimulated the economic growth of a country by transforming the innovative ideas into economically viable entities by creating a new business. But launching a new venture is a narrower concept entrepreneurial venture. Ekanem (2014) said that an entrepreneur can boost up the economic growth by entering an established market with existing goods or services also. In the view of Maritz (2008), the essential act of entrepreneurship is more than a new entry. According to Baumol (1993), the economic system is an important factor that promotes the economic development of a country. Obviously, it is but Meredith (1987) added that the total contribution of entrepreneurial activity in the long term and short term economic performance of a country cannot be avoided. Again Porter and Nagarajan (2005) stated that economic system is the key determinants of supporting the entrepreneurial activities. Ekanem, (2014) identified in his study that Pakistan is not economically strong due to the lack of the promotion of entrepreneurial activities. In early studies Baumol (1993) clearly stated that entrepreneurs act as an innovator which is the most important way of economic development of a society and entrepreneurs are the major contributor to the economic development of a country Maritz (2008) argued that the role of entrepreneurs in economic development and poverty reduction has been discussed mainly from the perspective of developing economies. Meredith (1987) suggested that this is because developing economies are weak in job creation and their structural development policies are not very much strong to support the entrepreneurial business activities. Moreover, people in developing economies have low business skills and innovation skills because they lack educational facilities and networking abilities. So, promoting the entrepreneurial activity in developing economy is more important.

\section{Wennekers and Thurik model for entrepreneurial activity to economic growth}

Recently two established models have succeeded in not restricting explanations for economic growth to the realm of macroeconomics. The related framework models are proposed by Wennekers and Thurik (1999) and the GEM research programme.

Wennekers and Thurik (1999) established the following model, relating entrepreneurial activity to economic growth:

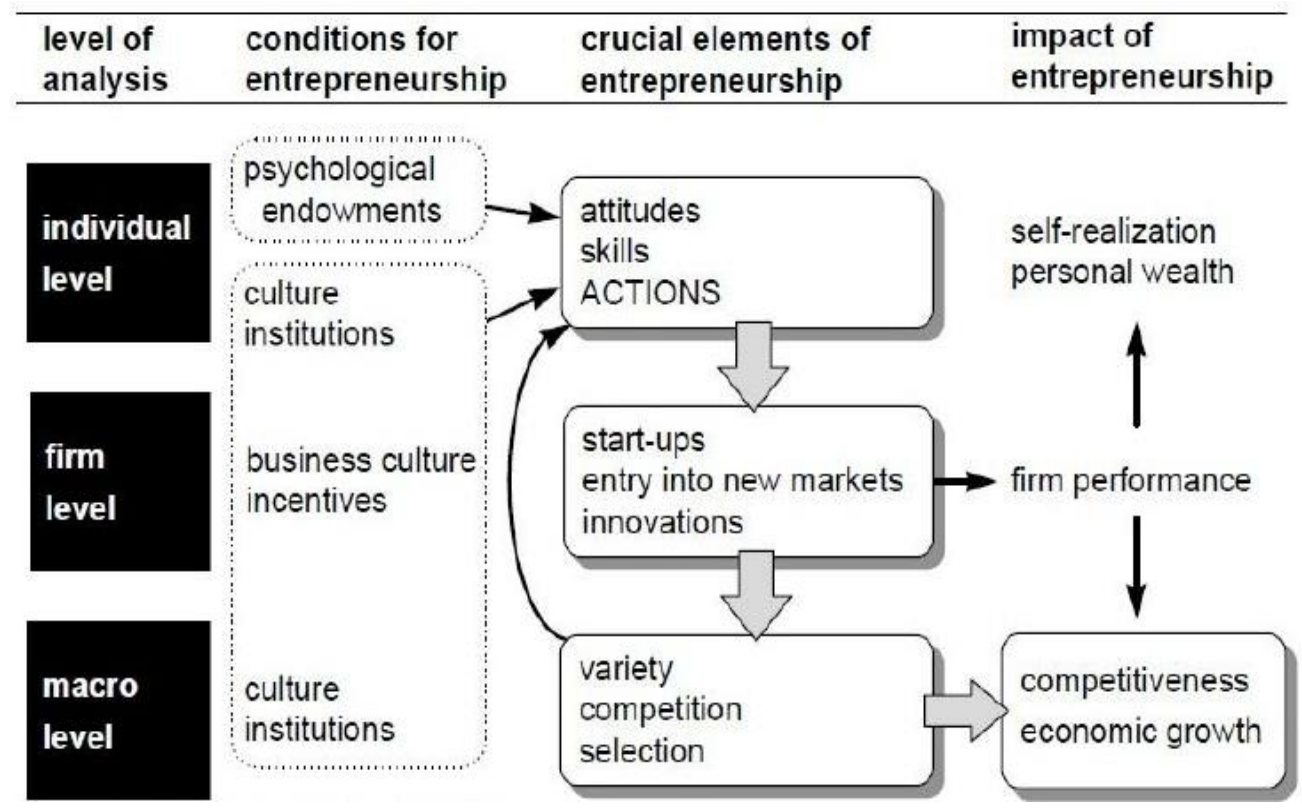

Figure 1. The Wennekers and Thurik model for entrepreneurial activity to economic growth

Source: Carree and Thurik (2002).

The model characterizes between three different levels of analysis and those are: the individual level, the firm level and the macro level. According to the model, entrepreneurial activity often begins at the individual level 
and is always visible to a single person, the entrepreneur. Entrepreneurship is, hence, induced by an individual's attitudes or motives, skills and psychological endowments. To be species, yet the individual entrepreneur is not commission entrepreneurial activities in a timeless and spaceless vacuum, but is affected by the context in which he or she is acting. Therefore, entrepreneurial motives and actions are influenced by cultural and institutional factors, the business environment and macroeconomic conditions.

While entrepreneurship begins at the individual level, but the initial realization is achieved at the firm level. Start-ups or innovations are vehicles for transforming personal entrepreneurial qualities and ambitions into actions. At the macro level of industries and national economies, the sum of entrepreneurial activities constitutes a mosaic of competing experiments, new ideas and initiatives. This competition leads to variety and change in the market - that is, a selection of the most viable firms, their imitation and a displacement of obsolete firms. Entrepreneurial activity hence expands and trans- forms the productive potential of the national economy by inducing higher productivity and an expansion of new niches and industries. Processes at the aggregate level are, in turn, linked to the individual layer, obviously including important feedback mechanisms for individual entrepreneurs. Entrepreneurs can learn from both their own and others' successes and failures, which enables them to improve their skills and adapt their attitudes (Caree and Thurik 2002: 19-20).

\section{The GEM conceptual model}

The conceptual framework of GEM drives into a marginally diverse viewpoint. Then it analyses the success of large firms advancing market opportunities for SMEs and the role of entrepreneurship in the enterprise creation/growth process as the main mechanisms driving macroeconomic growth along with their complementary nature.

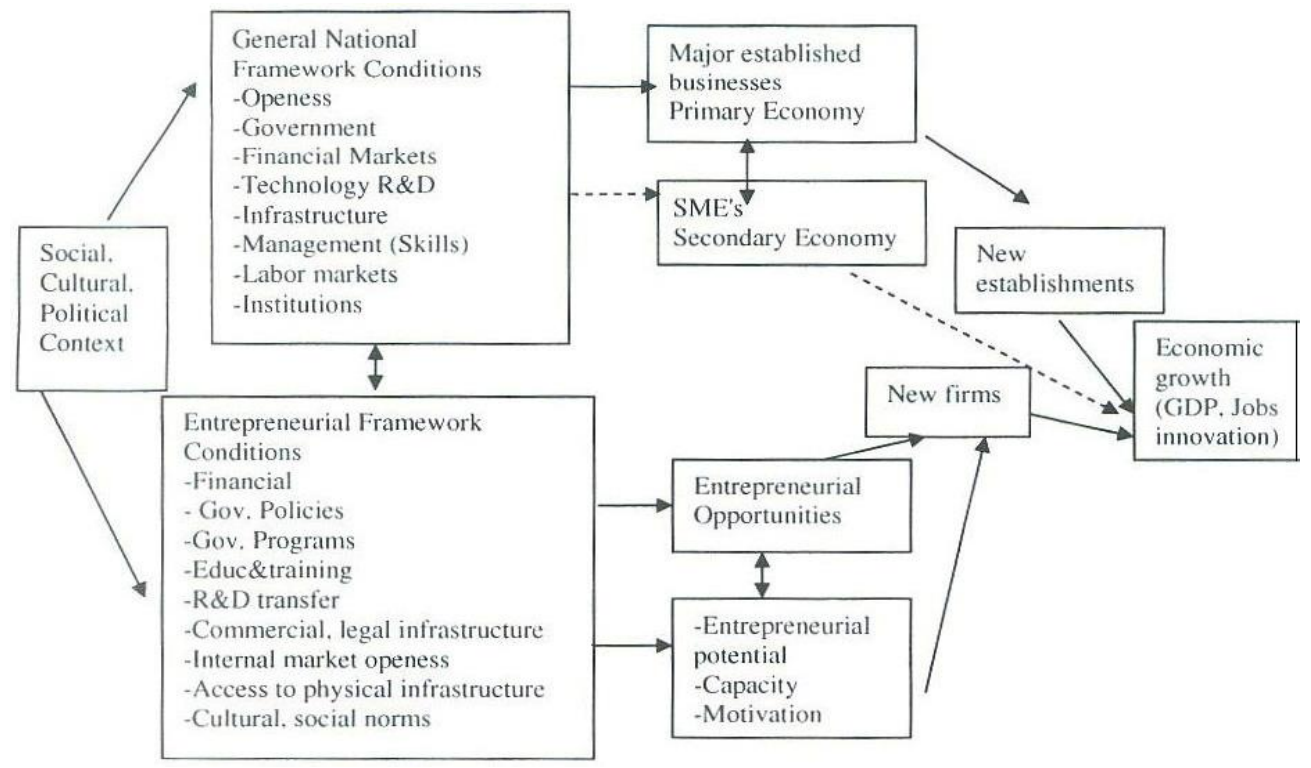

Figure 2. The GEM conceptual model

Source: Reynolds et al. (2002).

The top portion of GEM model focuses on the role of large established enterprises. Depending on national framework conditions, large firms, usually incorporated into international trade markets, can promote selfexpansion and maturation. The economic success of large enterprises tends to create new market opportunities for SMEs through technological spill-overs, spin-offs, an increase in domestic demand for goods and services, an integration of SMEs in supplier networks, and so forth. Yet whether domestic firms are able to seize these opportunities depends largely on the existence of a competitive and vibrant SME sector. The lower portion of GEM model highlights the second mechanism driving economic growth: the role of entrepreneurship in the creation and growth of firms. The entrepreneurial process occurs in the context of a set of framework conditions. It further depends on the emergence and presence of market opportunities and the capacity, motivation and skills of individuals to establish firms in pursuit of those opportunities. While the success of large established enterprises tends to create profit opportunities for small and new firms, these firms can also affect the success of large enterprises. For instance, by being competitive and reliable suppliers, SMEs provide a competitive advantage for large firms in global arenas (Reynolds et al. 2002). 


\section{The balanced view of international entrepreneurship and economic development}

Different authors provided different views about international entrepreneurship and economic development. Some literature supported the economic theory of entrepreneurship, some supported the resources based theory and some suggested the opportunity based theory. If we review all the literature about international entrepreneurship and economic development then we can see that all the theories are supported by various authors from different perspectives. There is an impact of entrepreneurial growth on the economic development of a country. Certainly, there is a relationship between international entrepreneurship and economic growth (Audretsch, 2001). Entrepreneurial activities limited in the local economy can boost up the economic growth but it can boost up the economic growth of an economy further by expanding the entrepreneurial activities through cross-border SMEs (Tan and Fan, 2013). Since entrepreneurs are the change agent of an economy, they can introduce a new product, new technology, and new process also by taking a risk about a new venture. Since key suppliers of the large firms are SMEs, these SMEs can go for cross-border business activity and improve the income growth of the country as well the productivity.

Porter and Nagarajan (2005)said that physical capital and networking both are important for entrepreneurial success. New businesses can acquire physical capital by introducing new technology or process and improve the FDI of a country. This capital will be helpful to improve the productivity i.e. GDP growth of the country and thus ensure the economic growth through international entrepreneurship. International entrepreneurship activities also create jobs for local people as well as people from overseas. Thus entrepreneurial activity can improve the GDP, employment rate, and business efficiency. International entrepreneurship increases the competitiveness among international SMEs (Autio, 2014). Besides, developing economies can introduce innovation and technological process which is a key factor that drives the growth of an economy. Acs (2006) developed a transmission channel for economic growth that ensures that entrepreneurial activity promotes economic development. The model of transition channel has been represented in Figure 1. Business entrepreneurship and economic development basically dependent on each other (Autor, Kerr and Kugler, 2007). This is because an improved and strong economy government try to promote the activities of small and new business enterprises since it increases the productivity of an economy and creates jobs for people. On the other hand, entrepreneurial activity is boosted up the economic growth positively as per the study of Berkowitz and Holland (2011). For this reason, entrepreneurial activity and economic development are supportive of each other.

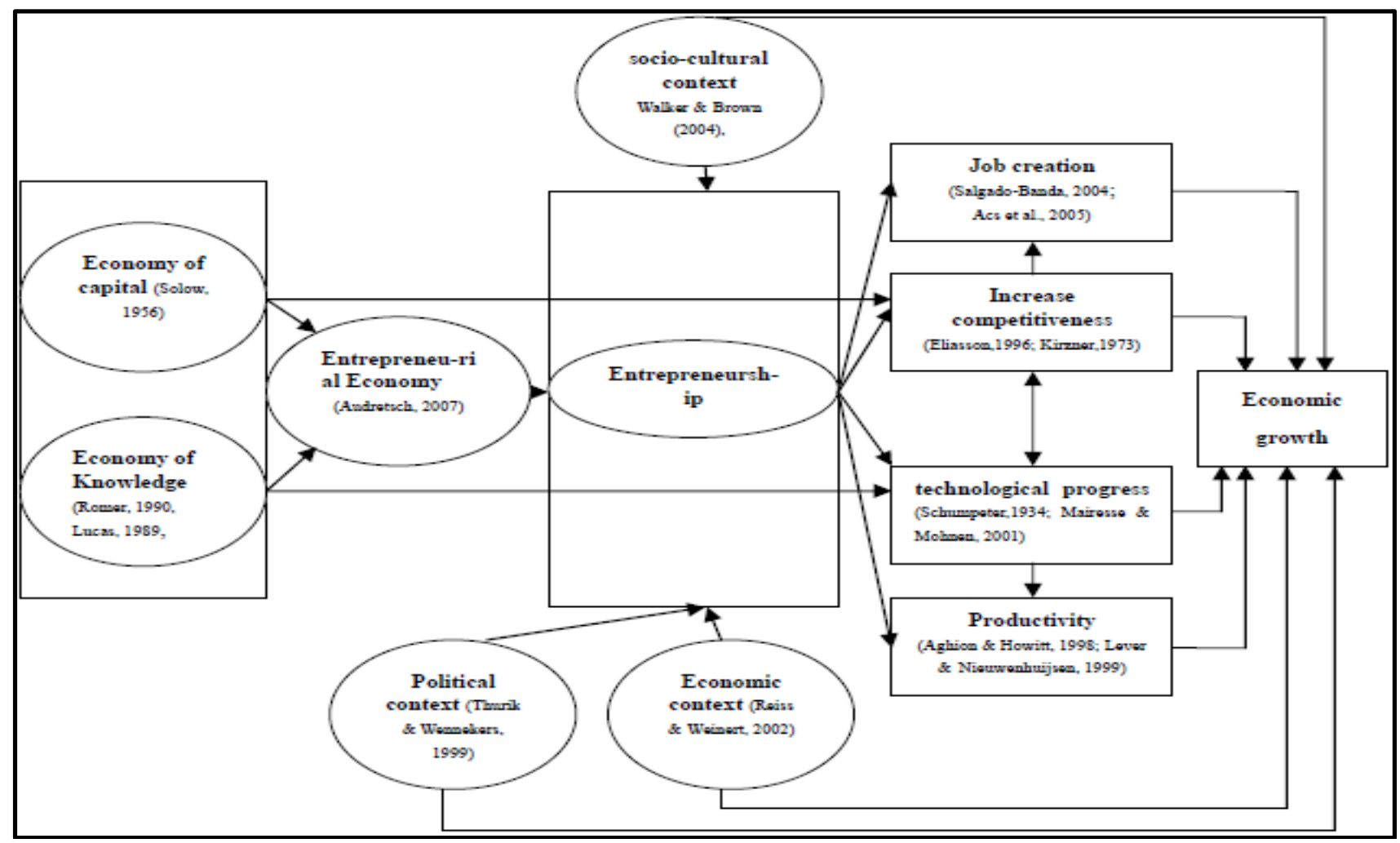

Figure 3. The model of transition channel

Source: Entrepreneurship and Economic Growth: The Transition Channel, Source: Acs (2006). 


\section{View of the researcher}

The researchers perceive that for the entrepreneurs or to set up a new business in a particular location, the entrepreneurs need to find out the opportunities available to them. If the entrepreneurs do not find the gap or proper opportunities, then the business can fail or may not flourish in that sense. The entrepreneurs also need adequate resources to support their plans or ideas. The economic condition where the entrepreneurs intend to start their business needs to be favourable. Without the favourable condition of the economy, the entrepreneurship may not prosper. Though it is observed that the small firms such as the boutique shop, restaurants and so on are available more in the business than the large firm, the contribution of the small firms is not less significant. The technologies and also research and development used by the companies are lower, but the economic and social development can be possible with the help of the small firms. Though the contribution of the small firms in the economy and GDP growth is little, it also facilitates the growth of the companies (Buckley, 1989). The large firms directly contribute to the development of the economy and the small firms play the supportive role in this regard. Sometimes the small firms play the supportive role in the development of the large corporations and also the large corporations also help the small firms to grow their business so that whole economy can be benefitted by the entrepreneurs (Cavusgil and Knight, 2015). Due to the entrepreneurial activity, the vast opportunity can be created and also the productivity and growth can be ensured by the organizations.

Though entrepreneurship is a risky project, innovative entrepreneurs introduce new invention and technological process to business firms and thus they influence productivity. The growth and the revolutionary changes can be managed by the entrepreneurship. The entrepreneurs are the game changers and all the world development are brought with the help of the entrepreneurs (Covin and Slevin, 1989). In the era of the globalization, all firms are linked to each other. In this ecosystem, if one is developed, the other organization also derives the benefits of the organization. With the introduction of the innovative and qualitative products, the betterment of the life of all people can be ensured. Due to the entrepreneurship, the employment is created in the market and also due to this; the social and ethical values can be developed by the companies. The present world can become more beautiful through the blessing of the entrepreneurs. The entrepreneurs especially the large firms can play the role of the social awareness among the general people and also ensure the development of the economy, market, nation and world to the large extent. Despite, the riskiness, different and unique movements of the entrepreneurs, it can be considered as a blessing to the people.

\section{Conclusion}

In spite of the global depression, entrepreneurs are enjoying facilities because governments provide conveniences to entrepreneurs in a variety of ways because any country can be productive within the boundary of entrepreneurial activities. Economic development can be approached through different ways such as structural change, government support, accumulation of human capital, urbanization, growing level of education, income distribution etc. The entrepreneurs play the leading role in this regard. Small business firms are created because of the increase in start-up businesses. But the reasons behind starting up new small businesses are that entrepreneurs are the routes of innovation and job generation. So all kind of entrepreneurship either it is large or small can be a blessing for the economy.

The current paper is been produced based on the secondary data specifically different literature, articles and book recommendations to justify how effective entrepreneurship activities help in economic developments and also creates more jobs. But matter of fact, the local governments existing around the globe isn't equal to each other in the strength of economy and also culture. So the effective entrepreneurship activities may possibly help in economic developments and creates more jobs but not for all. In depth future research can take place for particular country rather than overall to assess whether the entrepreneurship activities could be the right thing to promote for them or not.

\section{References}

1. Acs, Z. (2006). How Is Entrepreneurship Good for Economic Growth? Innovations: Technology, Governance, Globalization, 1(1), 97-107.

2. Audretsch, D. (2001). What's New about the New Economy? Sources of Growth in the Managed and Entrepreneurial Economies. Industrial and Corporate Change, 10(1), 267-315.

3. Autio, E. (2014). Creative tension: the significance of Ben Oviatt's and Patricia McDougall's article 'toward a theory of international new ventures'. Journal of International Business Studies, 36(1), 9-19.

4. Autor, D., Kerr, W. and Kugler, A. (2007). Does Employment Protection Reduce Productivity? Evidence 
From US States. The Economic Journal, 117(521), F189-F217.

5. Baumol, W. (1993). Formal entrepreneurship theory in economics: Existence and bounds. Journal of Business Venturing, 8(3), 197-210.

6. Berkowitz, D. and Holland, J. (2011). Does privatization enhance or deter small enterprise formation? Economics Letters, 74(1), 53-60.

7. Buckley, P. (1989). Foreign direct investment by small and medium sized enterprises: The theoretical background. Small Business Economics, 1(2), 89-100.

8. Carree, M., and A. Roy Thurik (2002). The Impact of Entrepreneurship on Economic Growth. In Zoltan Acs and David B. Audretsch (2003), International Handbook of Entrepreneurship Research, Boston/Dordrecht: Kluwer Academic Publishers.

9. Cavusgil, S. and Knight, G. (2015). The born global firm: An entrepreneurial and capabilities perspective on early and rapid internationalization. Journal of International Business Studies, 46(1), 3-16.

10. Covin, J. and Slevin, D. (1989). Strategic management of small firms in hostile and benign environments. Strat. Mgmt. J., 10(1), 75-87.

11. Davidsson, P. (1995). Culture, structure and regional levels of entrepreneurship. Entrepreneurship \& Regional Development, 7(1), 41-62.

12. Ekanem, I. (2014). Book review: Cross-border Entrepreneurship and Economic Development in Europes Border Regions. International Small Business Journal, 32(2), 228-230.

13. Etzioni, A. (1987). Entrepreneurship, adaptation and legitimation. Journal of Economic Behavior \& Organization, 8(2), 175-189.

14. Fletcher, R. (2011). A holistic approach to internationalisation. International Business Review, 10(1), 25-49.

15. Georgiou, M. (2011). Self-Employment Does Not Outweigh Long-Term Unemployment: A Panel Data Empirical Analysis for Europe (1999-2009). SSRN Electronic Journal.

16. Han, M. and McKelvey, B. (2008). Toward a social capital theory of technology-based new ventures as complex adaptive systems. International Journal of Accounting \& Information Management, 16(1), 36-61.

17. Ilmakunnas, P. and Kanniainen, V. (2001). Entrepreneurship, Economic Risks, and Risk Insurance in the Welfare State: Results with OECD Data 1978-93. German Economic Review, 2(3), 195-218.

18. Johnson, J. (2004). Factors Influencing the Early Internationalization of High Technology Start-ups: US and UK Evidence. Journal of International Entrepreneurship, 2(1/2), 139-154.

19. Koellinger, P. (2008). Why are some entrepreneurs more innovative than others? Small Business Economics, 31(1), 21-37.

20. Lumpkin, G. and Dess, G. (1996). Clarifying The Entrepreneurial Orientation Construct And Linking It To Performance. Academy of Management Review, 21(1), 135-172.

21. Maritz, A. (2008). Entrepreneurial Services Marketing Initiatives Facilitating Small Business Growth. Journal of Small Business \& Entrepreneurship, 21(4), 493-503.

22. McDougall, P. (1989). International versus domestic entrepreneurship: New venture strategic behavior and industry structure. Journal of Business Venturing, 4(6), 387-400.

23. Meredith, J. (1987). The strategic advantages of new manufacturing technologies for small firms. Strat. Mgmt. J., 8(3), 249-258.

24. Noorderhaven, N., Thurik, R., Wennekers, S. and Stel, A. (2004). The Role of Dissatisfaction and per Capita Income in Explaining Self-Employment across 15 European Countries. Entrepreneurship Theory and Practice, 28(5), 447-466.

25. Oviatt, B. and McDougall, P. (2005). Defining International Entrepreneurship and Modeling the Speed of Internationalization. Entrepreneurship Theory and Practice, 29(5), 537-554.

26. Porter, E. and Nagarajan, K. (2005). Successful Women Entrepreneurs as Pioneers: Results from a Study Conducted in Karaikudi, Tamil Nadu, India. Journal of Small Business \& Entrepreneurship, 18(1), 39-52.

27. Reynolds, Paul D., William D. Bygrave, Erkko Autio, Larry W. Cox and Michael Hay (2002). Global Entrepreneurship Monitor 2002 Executive Report. Wellesley, MA/London: Babson College/London Business School.

28. Scherer, F. (2002). The Free-Market Innovation Machine: Analyzing the Growth Miracle of Capitalism. By William J. Baumol. Princeton, NJ: Princeton University Press, 2002. Pp. xiv, 318. \$35.00. The Journal of Economic History, 62(03).

29. Tan, A. and Fan, T. (2013). Integrating International New Ventures and Staged Theory: Age at Entry, Survival and Growth. Academy of Management Proceedings, 1, 14042-14042.

30. Thurik, A., Carree, M., van Stel, A. and Audretsch, D. (2008). Does self-employment reduce 
unemployment? Journal of Business Venturing, 23(6), 673-686.

31. Yamada, G. (1996). Urban Informal Employment and Self-Employment in Developing Countries: Theory and Evidence. Economic Development and Cultural Change, 44(2), 289-314.

32. Wennekers, Sander, and Roy Thurik (1999). Linking entrepreneurship and economic growth. Small Business Economics, 13, 27-55.

33. Zahra, S. (2004). A theory of international new ventures: a decade of research. Journal of International Business Studies, 36(1), 20-28. 